\title{
Kernos
}

Revue internationale et pluridisciplinaire de religion grecque antique

15 | 2002

Varia

\section{Cassandra's Prophecy between Ecstasy and Rational Mediation}

Sabina Mazzoldi

\section{(apenEdition \\ Journals}

Electronic version

URL: http://journals.openedition.org/kernos/1373

DOI: $10.4000 /$ kernos. 1373

ISSN: 2034-7871

\section{Publisher}

Centre international d'étude de la religion grecque antique

\section{Printed version}

Date of publication: 1 January 2002

ISSN: 0776-3824

\section{Electronic reference}

Sabina Mazzoldi, «Cassandra's Prophecy between Ecstasy and Rational Mediation », Kernos [Online], 15 | 2002, Online since 21 April 2011, connection on 01 May 2019. URL : http:// journals.openedition.org/kernos/1373; DOI : 10.4000/kernos.1373 


\section{Cassandra's Prophecy}

\section{between Ecstasy and Rational Mediation}

The literary evidence concerning Cassandra highlights a coherent representation of the figure of the Troyan mantis and of her way of divining.

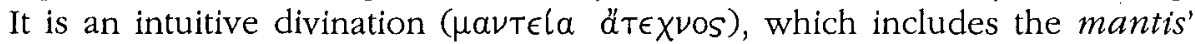
possession by Apollo (" condition of $\theta \in l a \mu a v l a$, which is the ground of the mantic inspiration. But the feature of Cassandra's divination is the alternation of two main phases, which are well detectable in many texts and represent two different psychological states. In the former Cassandra is presented in ecstasy and affected by visions, which she conveys verbally without rational mediation; in the latter the character seems to be self-possessed and she communicates her prophecies keeping her words under the control of rationality ${ }^{1}$.

Evidently, the main help to define the features of Cassandra's divination comes from the texts paying attention not only to the character, but also to divination as a religious and social phenomenon, and they become a possible key of interpretation. The presence of literary filter, the use of a poetic language, the revival (or the change) of a mythological tradition are data, which we must constantly remember not to imprudently consider the character a trustworthy transposition of the historical manteis. But it is true that Cassandra's figure falls consistently within the divination, historically attested $^{2}$, of the ecstatic and visionary type, and that some texts, which describe her or attribute her prophecies, become a precious reflection of an historical phenomenon - so prominent in the Mediterranean and Near East cultures ${ }^{3}$.

1 Cf. S. Mazzold, Cassandra, la vergine e l'indovina. Identità di un personaggio da Omero all'Ellenismo, Pisa/Roma, 2001, p. 94-95, 184-215.

2 Cf. A. Cooper, "Imagining Prophecy", in J.L. Kuged (ed.), Poetry and Propbecy: the Beginnings of a Literary Tradition, Ithaca, 1990, p. 26-44: 31 and n. 32.

3 Visions and experiences of ecstatic type connected to prophecy are testified in texts of many cultures and it is debated if they are a reflection of real experiences or if they have only traditional and literary character: $c f$. A. HuLTGR̊Rd, "Ecstasy and Vision", in N.G. Holm (eds.), Religious Ecstasy, Uppsala Stockholm, 1982, p. 218-225, with regard to Jewish and Iranian texts (p. 218: "there is therefore some justification in scrutinizing the texts in order to find evidence reflecting the seer's genuine experiences"). 
In this paper it is my aim, first of all, to examine Cassandra's divination in Aeschylus' Agamemnon, then I shall consider a passage of Plato's Timaeus about divination showing the same alternation of psychological states.

In the Aeschylean scene it is possible to reconstruct a particular divining process with the alternation of ecstasy and rationality. In fact, in this scene Cassandra seems subject to a climax of mantic ecstasy four times, less and less intense, which develops in four stages: A: cries and ritual invocations, B: clairvoyance without mediation, $C$ : clairvoyance with mediation, $D$ : rational prophecy. The first and second stages represent the first phase of divination, that is the conveyance of mantic knowledge from the divinity to the mantis (we will call it perceptive); the third and fourth stages represent the second phase of divination, when the prophetess is in contact with the audience of her prophetic message (we will call it communicative). Linguistical, syntactical and rhetorical features characterize each of these stages and justify their individuation ( $c f$. schema I).

1) The first stage, preceded by silence and immobility ${ }^{4}$, is characterized by the phenomenon of glossolalia ${ }^{5}$, which in fact appears usually in the ecstatic states; its function is to put the person in communication with the divinity and to give expression to his non-mediate presence. In Cassandra's divining process this stage constitutes the initial part of the clairvoyance, that is the contact with divinity, and it introduces the mantic visions. The cries ${ }^{6}$, only apparently incoherent, seem to mark out the beginning of her clairvoyance; they develop into invocations to Apollo of ritual type and then into rhetorical questions characterized by monological modulation.

2) The second stage consists of the visionary-access, which allows the knowledge of the past and of the future. In this stage the clairvoyant perceives the past and future reality through her whole person and her

$4 C f$. AEsch, $A g ., 1035$ sq. In all sequences stage's beginning coincides with verse's incipit and so is marked by a pause.

5 It is possible to define glossolalia as an "unintelligible extemporaneus postbabbling speech that exhibits superficial phonologic similarity to language without having consistent syntagmatic structure and that is not systematically derived from or related to known languages" (W.J. SAMARIN, "Variations and Variable in Religious Glossolalia", Language in Society 1 [1972], p. 121-130). The first who recognized in v. 1072 and 1076 the transcription of glossolalic utterances was L.J. Heirman, "Kassandra's Glossolalia", Mnemosyne 28 (1975), p. 257-267; afterwards Cassandra's glossolalia has been studied by S. CripPa ("Glossolalia. Il linguaggio di Cassandra", Studi italiani di linguistica teorica e applicata 19/3 [1990], p. 487-508; "Un genere oracolare? Ipotesi per un'analisi del linguaggio delle visioni", in E. BANFI (ed.), Atti del secondo incontro internazionale di Linguistica greca, Trento, 1997 (Labirinti, 27), p. 121-142), who points out the ecstatic and religious character of the glossolalic phenomenon.

6 In most texts Cassandra begins her prophecy with a cry: Pind., Pae., 8a, 10

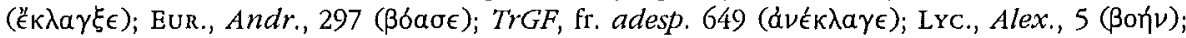

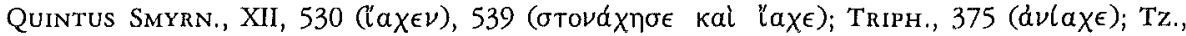
Posthom., 709 (Bodarke). 
senses (sight, hearing, smelling, taste, touch) ${ }^{7}$ and she conveys it without mediation and interpretation, that is without using rationality. The conveyance of the visions is simultaneous with the perception; so the visions themselves seem present and actual, and there is no separation between the different temporal levels. The sentences - a simple description by the claivoyant of visions sent by the god $^{8}-$ are often badly-constructed 9 and founded on a persistent use of the demonstrative adjective and pronoun and on the use of present tense alone (oracular synchronic tense) ${ }^{10}$. The use of the Deixis am Pbantasma and the temporal non-coherence are frequent in oracular contexts ${ }^{11}$. Since the difference between the divine language and the human language is by no means minimized, the oracular message appears obscure and ambiguous in the highest degree and so any interlocution with the chorus is impossible: in fact the verbal modulation of Cassandra appears substantially monological. The chorus, on the other hand, does not understand her words ${ }^{12}$, distorts their meaning ${ }^{13}$, refuses the message ${ }^{14}$, and when it concerns something well-known or understandable, is afraid of $\mathrm{it}^{15}$.

7 Of course for the clairvoyant the sight is the most important sense and her mantic knowledge comes from it: the visions, which are in front of Cassandra's eyes, are thick and overcome one another; she is able to understand what they mean step by step ( $c f . \mathrm{v}$. $1100,1107,1114)$. But the mantic experience involves the physiological sphere as a whole: on hearing $c f . \mathrm{v}$. 1117-1118, on smelling $c f$. v. 1092-1094, 1309; on taste $c f$. v. 1097, 1222; on touch $c f$. v. 1256, 1277-1278 (for a detailed analysis of these passages $c f$. MAzzoldi, o.c. [n. 1], p. 204-210). An extraordinary and abnormal sensorial perception is a Delphic pre-

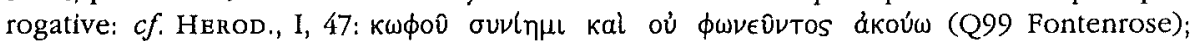

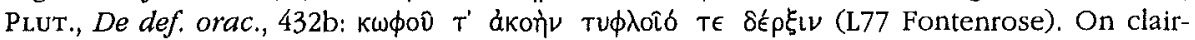
voyants' possibility to perceive by senses what common people can not $c f$. W. BURKERT, Griechische Religion der archaischen und klassischen Epoche, Stuttgart, 1977, p. 178.

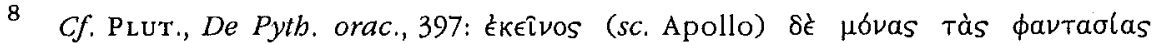

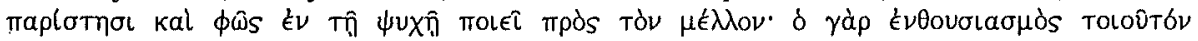
ÉoTl.

9 Noun sentences and participial phrases without finite verbs: v. 1091-1092, 1096$1097,1108-1109,1115-1116,1214,1219-1220$; lack of subject or change of subject without notice: v. $1100,1102,1110-1111,1127-1128$.

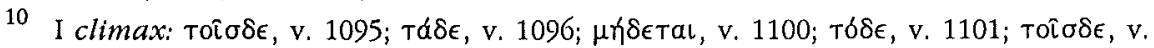

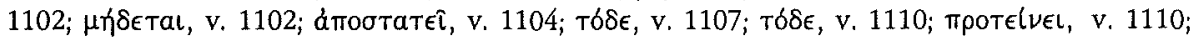

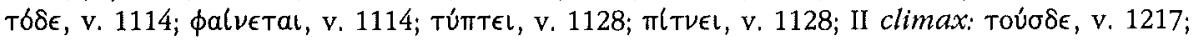

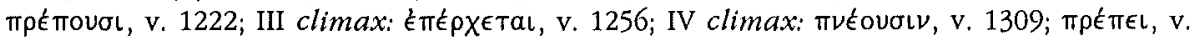
1311.

11 Cf. CRIPPA, "Un genere oracolare", supra (n. 5), p. 135-136, and ead., "La voce e la visione. Il linguaggio oracolare femminile", in I. Chirassi Colombo, T. Seppilit (eds.), Sibille e linguaggi oracolari. Mito Storia Tradizione. Atti del convegno, Macerata-Norcia, settembre 1994, Macerata, 1998, p. 159-189: 179-181.

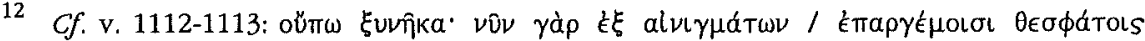
ả

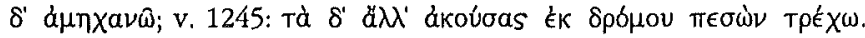

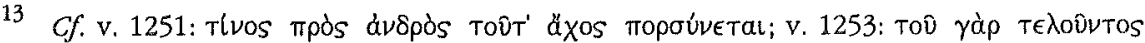

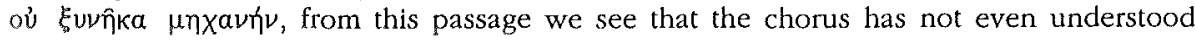


3) The third stage constitutes the transition from visionary-ecstasy to rational prophecy: Cassandra still lives in the vision context, but communicates it through her rationality. Sentences are well-constructed and the use of verbal tenses is consistent ${ }^{16}$. The use of metaphors and similes in her communication, typical of oracular language represents the claivoyant's attempt to approach the meaning of visions step by step and through the association of ideas ${ }^{17}$. In this stage Cassandra interprets the events, which have become known to her, by using similes, finding causal nexus and mourning them. Now the communication with the chorus does become possible, and a kind of dialogue does begin, initially hesitant and frequently cut, then more and more permanent and close.

4) The fourth stage is the real prophecy: Cassandra turns all her attention to the communication ${ }^{18}$ and intervenes by rationality to render the message as understandable as possible. The exposition of prophecies in a clear style is the result of programmatic choices and statements and corresponds to the return of a normal use of verbal tenses and to a complete autonomy of interpretation and judgement. The predicted events are connected by strong temporal and causal consequence. The dialogue with the chorus becomes closer and closer up to the stichomythia.

In the Aeschylean scene these four stages do follow each other, as it were, in a descending climax of ecstasy four times, so that it is possible to single out four sequences A-D; each of them starts with a new cry, of glossolalic type, which marks the access of ecstasy and the conscience leap

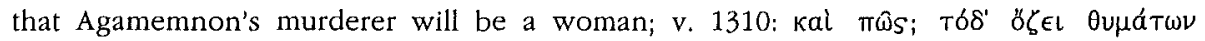

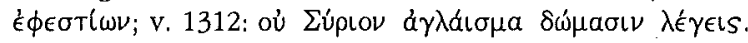

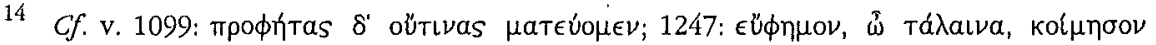
бто́нa.

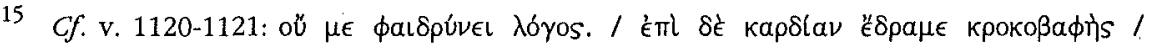

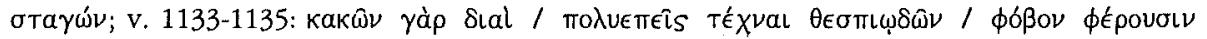

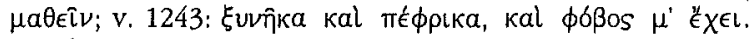

$16 C f . \xi v v \theta a \nu 0 u \mu \epsilon \eta \eta \nu, v .1139 ; \mu(\mu \nu \epsilon \mathrm{l}$, v. 1149 (in the latter case the future is implied by

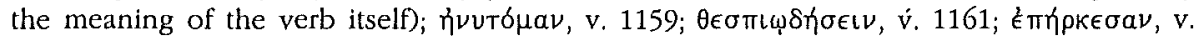

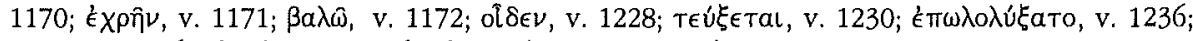

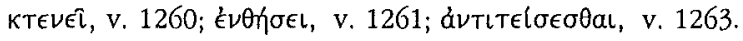

17 I climax: Clytemnestra $=$ cow, Agamemnon = bull (v. 1125-26); II climax: Aegisthus $=$ lion (v. 1223-1225); Clytemnestra $=\operatorname{dog}(\mathrm{v}, 1228) ;$ Clytemnestra $=$ monster, Amphisbaina, Scylla, Hades' mother (v. 1232-1236); III climax: Clytemnestra $=$ lioness, Aegisthus $=$ wolf, Agamemnon $=$ lion (v. 1258-1259); IV climax Cassandra $=$ bird (v. 1316). Cf. E. Grassi, Potenza dell'immagine. Rivalutazione della retorica, Milano, 1989, p. 97-98 (on Cuman Sibyl of Vergil): "il linguaggio semantico della Sibilla è intessuto di metafore, immagini, che appaiono sempre quando la profetessa vuole rendere comprensibile il significato di qualcosa che si palesa direttamente. La metafora sostituisce la chiarificazione razionale... L'unità, la sintesi tra le diverse immagini nasce per 'associazione' non per 'spiegazione', in un'improvvisa visione di similitudini".

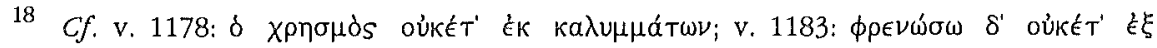
alvı $\gamma \mu$ át $\omega \nu$. 
in the clairvoyance. But, since in the scene Cassandra's divination develops into a more intelligible degree, the stages repeat themselves with different extension and have different importance in each climax, as it comes out from the scheme II, where the verses of each stage and the total numer of them are indicated.

It is possible to find out the four stages reconstructed in the Agamemnon also in other texts concerning Cassandra, either in the same sequence or alone $^{19}$, for the feature of her divination, as we have said before, is just the alternation of ecstasy and rational mediation. By simplifying the complex development of divining process as presented in Aeschylus' Agamemnon, we could say that Cassandra is either eैk $\phi \rho \omega \nu$ (that is $\epsilon^{\prime \prime} \nu \theta \in O S$ ), when she is represented in state of ecstatic-visionary inspiration and conveys visions without rational mediation, or she is $\epsilon^{\prime} \mu \phi \omega \nu$, when she is represented not in ecstasy and interprets her own visions ${ }^{20}$, puts them into a temporal and logical succession, communicates them through intelligible words and wellconstructed sentences to render them understandable by the audience. This does not mean that in the first phase Cassandra is thought of as 'irrational': it does only mean that phren and logos work at a level which is consistent with the divine, but it is different in comparison with that of human rationality, so her message is consistent with visions sent by divinity, but seems irrational and incomprehensible for man. In the second phase, on the contrary, the prophetess' effort to make her logos consistent with the audience's phren emerges clearly.

This alternation of psychological states seems to find a remarkable expression in Platonic Timaeus ${ }^{21}$. In fact, in his famous monologue Timaeus,

19 The most evident examples are in late epic poetry: both in Quintus Smyrnaeus and in Triphiodorus we can find the initial cry, the stage of visions in the present tense (QuINTUS SMYRN., XII, 540-543, 548-549; TRIPH., 391-394), the stage of mediate clairvoyance in the future tense and the metaphors (Quintus SMYRN., XII, 546; TrIPH., 382-390, 398-407), finally the stage of rational prophecy with awareness of surrounding reality (QuINTUs SMYRN., XII, 549-551; Triph., 410-416).

20 Also P. MURray, in an article on poetic inspiration ("Poetic Inspiration in Early Greece", JHS 101 [1981], p. 87-100: 94), attracts attention on the difference between ecstatic inspiration of visionary type and non-ecstatic inspiration; A. IRIARTE (Las redes del enigma. Voces femeninas en el pensamiento griego, Madrid, 1990, p. 104-114, 118-119) believes that these two states, which provide two different ways of expression, agree with female and male genders.

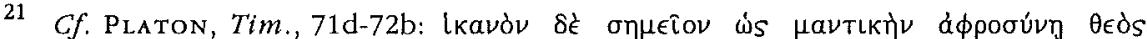

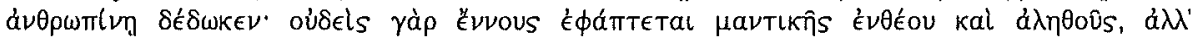

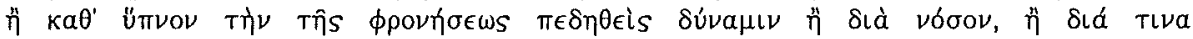

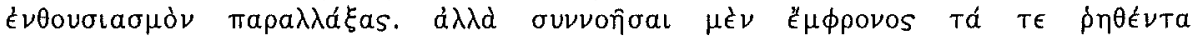

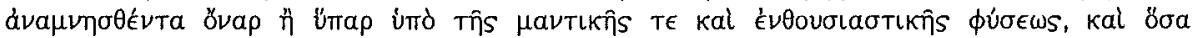

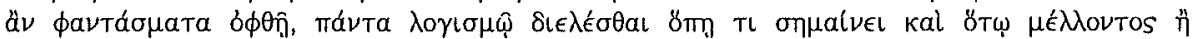

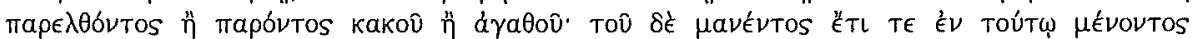
oủk है

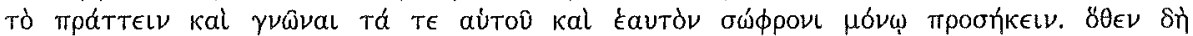


when he describes the function of the body's different organs, dwells upon the liver and particularly on the soul's part that stays in the region of the liver and is endowed with divination, since it has part neither in $\lambda 6 \gamma$ os nor in

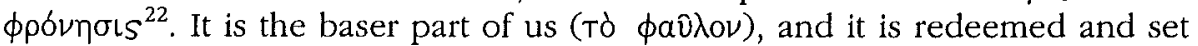
on the right path, because it might have some apprehension of reality and

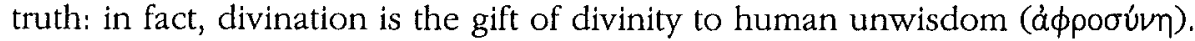
In order to explain what it means, Timaeus seems to appeal to a common

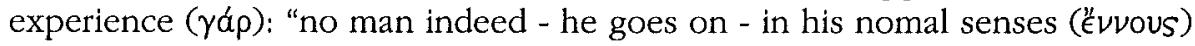
deals in true and inspired divination, but only when the power of understanding is fettered in sleep or he is distraught by some disorder or, it may be, by divine possession. It is for the man in his ordinary senses ( $\epsilon^{\prime} \mu \phi \rho \omega \nu$ ) to recall and construe the utterances, in dream or in waking life, of divination

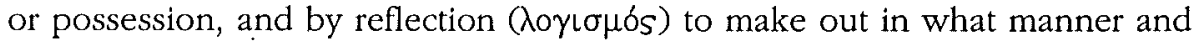
to whom all the visions of the seer betoken some good or ill, past, present, or to come. When a man has fallen into frenzy and is still in that condition, it is not for him to determine the meaning of his own visions and utterances; rather the old saying is true, that only the sound in mind ( $\sigma \omega \phi \rho \omega \nu$ ) can attend to his own concerns and know himself"23. From the passage we can clearly observe the distinction between the man ouk Evvous ( $\delta \mu a v \epsilon i s$ ), endowed

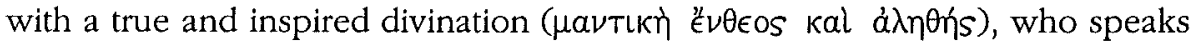

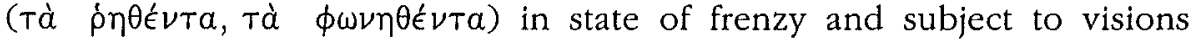
( $\phi \alpha \nu \tau \alpha ́ \sigma \mu \alpha T \alpha, \tau \grave{\alpha} \phi \alpha \nu \epsilon ́ \nu T \alpha)$, and the man in his ordinary senses ( $\epsilon^{\prime \prime} \mu \phi \rho \omega \nu$, $\sigma \omega \phi \rho \omega \nu$ ), who is able to understand ( $\sigma \nu \nu \nu o \hat{\sigma} \sigma a \mathrm{l}$ ) utterances and visions, to construe them $\left(\delta \imath \epsilon \lambda \epsilon^{\prime} \sigma \theta \alpha \mathrm{l}\right)$ in relation to the temporal consequence (future, past and present), to interpret and to give them the correct meaning ( $\kappa p(\nu \in \downarrow \nu)$. Thus it seems that utterances and visions become accessible to human comprehension. But the point is that Timaeus is referring evidently to two

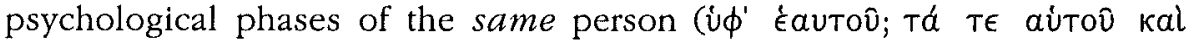

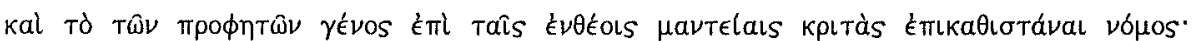

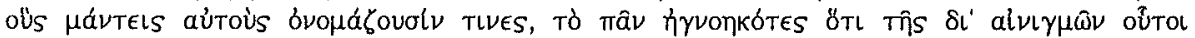

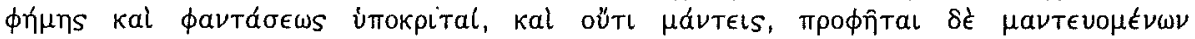

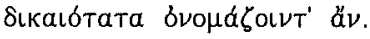

22 On divination in Plato cf. P. VICAIRE, "Platon et la divination", $R E G 83$ (1970), p. 333-350.

23 Transl. by F. M. Cornford, Plato's Cosmology. The Timaeus of Plato, transl. with a running comm. by-, London, 1935, p. 288-289. On soul's sensitivity to phantasy and precognitions, when it is free from reasoning $c f$. also Plut., De def. orac., 432c-d: taútᄁv

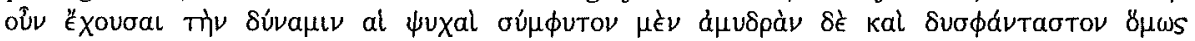

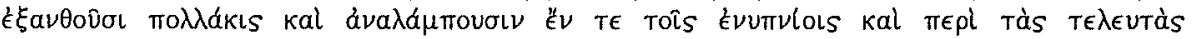

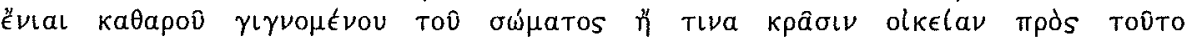

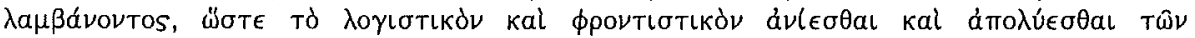

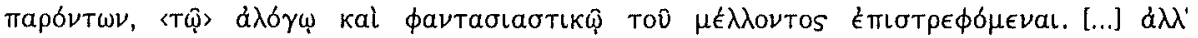

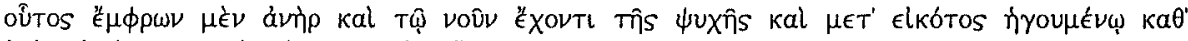

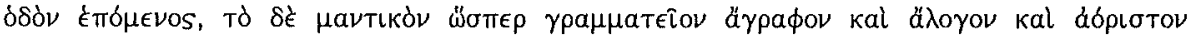

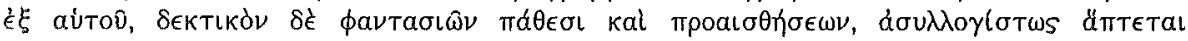

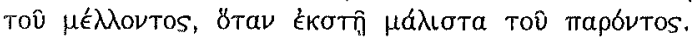


ÉauTóv): so Plato's passage constitutes a strong parallel with the divination of Cassandra.

Up to now I have discussed two literary texts. Do Cassandra's and Timaeus' divination have a recognizable historical background? In continuing his discourse, Timaeus does make a remarkable terminological distinction, which is unparalleled in literary evidence ${ }^{24}$, between two classes

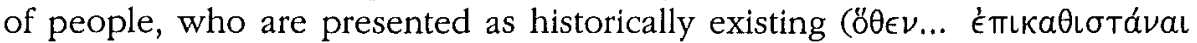

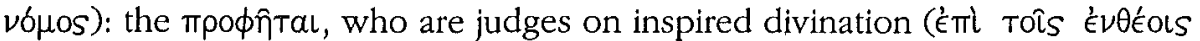

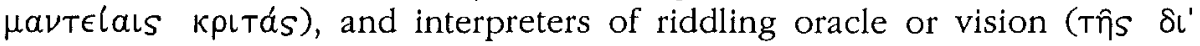

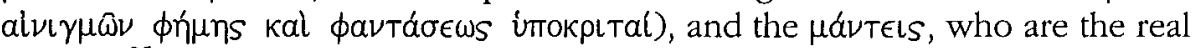

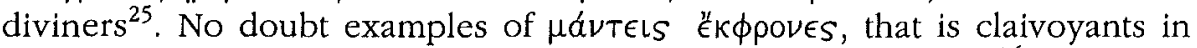
ecstatic state (we can think of Pythia figure or of Sibylline model) ${ }^{26}$, as well as

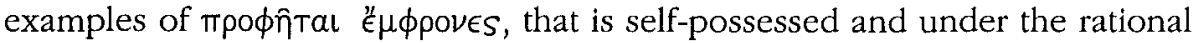
control, are present in Greek literary tradition and much probably both existed in historical reality. Even if Delphi is not mentioned, various scholars have already thought that Plato, when he describes the divining way as involvement of the diviner, who sees, and of the prophet, who exposes, is keeping in mind the different functions of the Pythia, inspired $\mu \alpha \nu \tau, s$, and of the Priests, her spokesmen ${ }^{27}$. On the other hand, the connections between Cassandra's language and the Delphic formulary (lexicon, animal metaphors, concrete instead of abstract, periphrasis) are so prominent that Parke and Wormell assert that "the Cassandra's language is modelled on that of the Delphic responses, and there can be little doubt that she herself is in part the dramatic representation of the Pythia in ecstasy" ${ }^{28}$. Moreover, the mantic climax' structure itself, I detected in the Agamemnon, has the same thematic sequence which Fontenrose has found in the typical structure of Delphic responses: the evocation formula, of glossolalic type ${ }^{29}$, and the invocation -

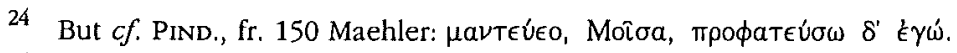

25 Cf. G. NAGY, "Ancient Greek Poetry, Prophecy, and Concepts of Theory", in J.L. KugeL (ed.), Poetry and Propbecy: the Beginnings of a Literary tradition, Ithaca, 1990, p. 56-64: 60: "from the standpoint of the Platonic passage at hand, the inspiration of the mantis is a given, a matter of Greek religious institutions. The noninspiration of the prophetes is also a given, again a matter of Greek religious institutions".

26 On a comparison between the figures of Cassandra, the Pythia and Sibyl $c f$. Mazzoldi, o.c. (n. 1), p. 99-107; more specifically on the differences between Pythia's and Sibyl's prophetic inspiration $c f$. CRIPPA, "La voce e la visione", supra (n. 11), p. 162-163, 176-182, 186-187.

27 Cf. Arcer-Hind, The Timaeus of Plato, London, 1888, ad loc; A.E. TAylor, $A$ Commentary on Plato's Timaeus, Oxford, 1928, p. 514; P. AMANDRY, La mantique apollinienne à Delphes. Essai sur le fonctionnement de l'oracle, Paris, 1950, p. 55; M. Delcourt, L'oracle de Delphes, Paris, $1981^{2}$, p. 228 n. 1.

28 H.W. Parke, D.E. Wormell, The Delphic Oracle I-II, Oxford, 1956, II, p. xxxv. On this argument $c f$. also CRIPPA, "Un genere oracolare", supra (n. 5), p. 123-127, 134.

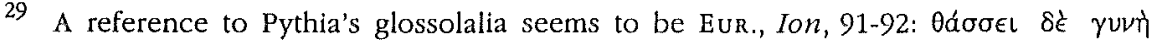

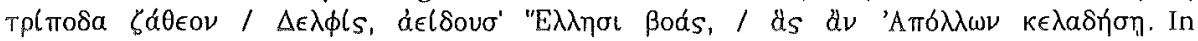


typical elements of the so-called salutation to divinity ${ }^{30}$ - are followed by the recalling of past and critical events ('condition precedent', it may be expressed in a participial phrase), then by the prophecy itself and by the assertion of mantic authority (vaticinium ex eventu); finally by the 'explication', that is the interpretation and judgement on prophecies ${ }^{31}$. By noting the constant presence of oracular situations in all tragedies, which we can read entirely (with the exception of Aeschylus' Suppliants), and by comparing some tragic linguistic features with the formulary of oracular responses, it is possible to assume that the Delphic sanctuary wielded a clear cultural influence over the Athenian theater. Particularly in Aeschylean texts the purpose of the resorting to oracular technic vocabulary seems to be the evocation of foresight's sacral feature and it gives evidence to the ritual's strong permanence ${ }^{32}$. We can conclude that in 458 B.C., in the Athenian theater of Dionysos, Aeschylus meant to represent the divination in a rather realistic way as a religious and social phenomenon. In his Cassandra endowed with the dual nature of $\mu \alpha \dot{\nu T L S}$ and $\pi \rho \circ \phi \eta T \eta \eta s$, a literary figure of an unbelieved foreteller - we can see the reflection of an oracular practice, which was a part of Athenians' common experience and which found the most famous concrete form in Delphi, where the institution itself provided the co-existence of the Pythia and her interpreters ${ }^{33}$.

Sabina MAZZOLDI

Via Sagginalese 2,

I - 50032 Borgo S. Lorenzo (FIRENZE)

e-mail: smazzoldi@univr.it

TAYLOR'S opinion (o. c., p. 513), $\gamma \lambda \omega \sigma \sigma o \lambda a \lambda(\alpha$ itself could be a good model of what Timaeus does mean by saying prophetic vóool. On the interpreter figure in relationship with glossolalia $c f$. CRIPPA, "Glossolalia", supra (n. 5), p. 499 and n. 19 with bibliographic references. The analysis of Pythia's and Cassandra's language allows to reconstruct the true nature of it, which testifies the presence of glossolalic phenomenon in Greek culture too (cf. Crippa, "Glossolalia", supra [n. 5], p. 500-501).

30 Cf. CRIPPA, "Un genere oracolare", supra (n. 5), p. 137.

31 Cf. J. Fontenrose, The Delphic Oracle, Berkeley, 1978, p. 175-185.

32 Cf. M. Cavalli, "Tragedia e cultura oracolare. Alcune osservazioni", Dioniso 62 (1992), p. 49-68: 49-50, 64; S. Vogt, "Delphi in der attischen Tragödie", AA 44 (1998), p. 3048: 34, 41-44, 48.

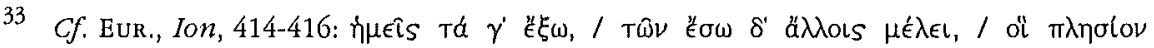

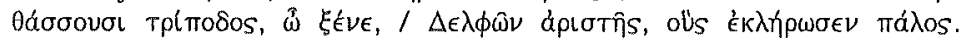




\section{Schema I}

\begin{tabular}{|c|c|}
\hline $\begin{array}{l}\text { I phase 'perceptive': } \\
\text { ecstasy, visions, } \\
\text { in contact with divinity }\end{array}$ & $\begin{array}{l}\text { Stage A: glossololia } \\
\text { (preceded by silence, immobility) } \\
\text { - cries, ritual invocations } \\
\text { Stage B: clairvoyance without mediation } \\
\text { - visions and perception by senses } \\
\text { \# soliloquy without interlocution } \\
\text { " badly-constructed sentences } \\
\text { Deixis am Phantasma and present tense }\end{array}$ \\
\hline $\begin{array}{l}\text { II phase 'communicative': } \\
\text { consciousness, knowledge, } \\
\text { in contact with human audience }\end{array}$ & $\begin{array}{l}\text { Stage C: clairvoyance with mediation } \\
\text { - rational interpretation of visions } \\
\text { \# awareness of audience's presence } \\
\text { " well-constructed sentences } \\
\text { causal nexus, use of metaphors for visions, } \\
\text { past and future tense } \\
\text { Stage D: rational prophecy } \\
\text { - rationality, interpretation and judgement } \\
\text { on prophecies } \\
\text { \# will to communicate, dialogue } \\
\text { (sticbomythia) } \\
\text { "temporal and causal consequence } \\
\text { normal use of tenses }\end{array}$ \\
\hline
\end{tabular}




\section{Schema II}

\begin{tabular}{|c|c|c|c|c|}
\hline & $\begin{array}{c}\text { stage } \mathbf{A} \\
\text { glossolalia: } \\
\text { cries and ritual } \\
\text { invocations } \\
\end{array}$ & $\begin{array}{c}\text { stage B } \\
\text { clairvoyance } \\
\text { without } \\
\text { mediation } \\
\end{array}$ & $\begin{array}{c}\text { stage C } \\
\text { clairvoyance with } \\
\text { mediation }\end{array}$ & $\begin{array}{l}\text { stage } \mathbf{D} \\
\text { rational prophecy }\end{array}$ \\
\hline I climax & $\begin{aligned} & 1072-73 \\
& 1076-77 \\
& 1080-82 \\
& 1085-87 \\
&=10 \text { verses }\end{aligned}$ & $\begin{aligned} & 1090-92 \\
& 1095-97 \\
& 1100-04 \\
& 1107-11 \\
& 1114-18 \\
& 1125-29 \\
&=26 \text { verses } \\
&\end{aligned}$ & $\begin{array}{r}1136-39 \\
1146-49 \\
1156-61 \\
1167-72 \\
=20 \text { verses } \\
\end{array}$ & $\begin{array}{c}1178-97 \\
1202-03 \\
1206 \\
1208 \\
1210 \\
1212 \\
=26 \text { verses } \\
\end{array}$ \\
\hline II climax & $\begin{aligned} & 1214 \\
= & 1 \text { verse }\end{aligned}$ & $\begin{aligned} & 1215-22 \\
= & 8 \text { verses }\end{aligned}$ & $\begin{aligned} & 1223-38 \\
= & 16 \text { verses }\end{aligned}$ & $\begin{array}{c}1239-41 \\
1246 \\
1248 \\
1250 \\
1252 \\
1254 \\
=8 \text { verses }\end{array}$ \\
\hline III climax & $\begin{aligned} & 1256-57 \\
&= 2 \text { verses } \\
&\end{aligned}$ & $\begin{aligned} & 1256 \\
&= 1 \text { verse } \\
&\end{aligned}$ & $\begin{aligned} & 1258-78 \\
&= 21 \text { verses } \\
&\end{aligned}$ & $\begin{array}{c}1279-94 \\
1299 \\
1301 \\
1303 \\
1305 \\
=20 \text { verses } \\
\end{array}$ \\
\hline IV climax & $\begin{aligned} & 1307 \\
&= 1 \text { verse } \\
&\end{aligned}$ & $\begin{aligned} & 1309 \\
& 1311 \\
&= 2 \text { verses } \\
&\end{aligned}$ & $=0$ verses & $\begin{aligned} & 1313-20 \\
& 1322-30 \\
&= 17 \text { verses } \\
&\end{aligned}$ \\
\hline
\end{tabular}

